\title{
INTERNATIONAL POLITICAL ECONOMY SERIES
}

General Editor: Timothy M. Shaw, Professor of Political Science and International Development Studies, and Director of the Centre for Foreign Policy Studies, Dalhousie University, Nova Scotia, Canada

Recent titles include:

Pradeep Agrawal, Subir V. Gokarn, Veena Mishra, Kirit S. Parikh and Kunal Sen ECONOMIC RESTRUCTURING IN EAST ASIA AND INDIA

Perspectives on Policy Reform

Solon L. Barraclough and Krishna B. Ghimire

FORESTS AND LIVELIHOODS

The Social Dynamics of Deforestation in Developing Countries

Jerker Carlsson, Gunnar Köhlin and Anders Ekbom

THE POLITICAL ECONOMY OF EVALUATION

International Aid Agencies and the Effectiveness of Aid

Edward A. Comor (editor)

THE GLOBAL POLITICAL ECONOMY OF COMMUNICATION

O. P. Dwivedi

DEVELOPMENT ADMINISTRATION

From Underdevelopment to Sustainable Development

John Healey and William Tordoff (editors)

VOTES AND BUDGETS

Comparative Studies in Accountable Governance in the South

Nocleen Heyzer, James V. Riker and Antonio B. Quizon (edirors)

GOVERNMENT-NGO RELATIONS IN ASIA

Prospects and Challenges for People-Centred Development

George Kent

CHILDREN IN THE INTERNATIONAL POLITICAL ECONOMY

Laura Macdonald

SUPPORTING CIVIL SOCIETY

The Political Role of Non-Governmental Organizations in Central America

Gary McMahon (editor)

LESSONS IN ECONOMIC POLICY FOR EASTERN EUROPE FROM

LATIN AMERICA 
Juan Antonio Morales and Gary McMahon (editors)

ECONOMIC POLICY AND THE TRANSI'TION TO DEMOCRACY

The Latin American Experience

Paul Nelson

THE WORLD BANK AND NON-GOVERNMENTAL ORGANIZATIONS

The Limits of Apolitical Development

Archibald R. M. Ritter and John M. Kirk (editors)

CUBA IN THE INTERNATIONAL SYSTEM

Normalization and Integration

Ann Seidman and Robert B. Seidman

STATE AND LAW IN THE DEVELOPMENT PROCESS

Problem-Solving and Institutional Change in the Third World

Tor Skålnes

THE POLITICS OF ECONOMIC REFORM IN ZIMBABWE

Continuity and Change in Development

John Sorenson (editor)

DISASTER AND DEVELOPMENT IN THE HORN OF AFRICA

Howard Stein (ediror)

ASIAN INDUSTRIALIZATION AND AFRICA

Stuclics in Policy Altcrnatives to Structural Adjustıment

Deborah Stienstra

WOMEN'S MOVEMENTS AND INTERNATIONAL ORGANIZATIONS

Larry A. Swatuk and Timothy M. Shaw (editors)

THE SOUTH AT THE END OF THE TWENTIETH CENTURY

Rethinking the Political Economy of Foreign Policy in Alrica, Asia, the

Caribbcan and Latin America

Sandra Whitworth

FEMINISM AND INTERNA'TIONAL RELATIONS 


\section{The Move to \\ the Market?}

\section{Trade and Industry Policy Reform in Transitional Economies}

Edited by

\section{Paul Cook}

Senior Lecturer in Economics

The University of Manchester

and

Frederick Nixson

Reader in Economics

The University of Manchester

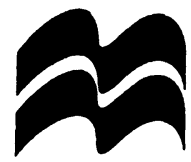


Selection, editorial matter and Chapter I $\odot$ Paul Cook and Frederick Nixson 1995 Chapters 2-15 @ Macmillan Press Lid 1995

Softcover reprint of the hardcover 1st edition 1995

All rights reserved. No reproduction, copy or transmission of this publication may be made without written permission.

No paragraph of this publication may be reproduced, copied or transmitted save with written permission or in accordance with the provisions of the Copyright, Designs and Patents Act 1988, or under the terms of any licence permitting limited copying issued by the Copyright Licensing Agency, 90 Tottenhan Court Road, London WIP 9HE.

Any person who does any unauthorized act in relation to this publication may be liable (1) criminal prosecution and civil claims for damnges.

First published in Great Britain 1995 by

MACMILLAN PRESS LTD

Houndmills, Basingstoke, Hampshire RG21 2XS

and London

Companies and representatives

throughout the world

A catalogue record for this book is available

from the British Library.

ISBN 978-1-349-24048-7

ISBN 978-1-349-24046-3 (eBook)

DOI 10.1007/978-1-349-24046-3

$\begin{array}{rrrrrrrr}10 & 9 & 8 & 7 & 6 & 5 & 4 & 3\end{array}$

$\begin{array}{llllllll}(1) & 03 & 02 & 01 & 00 & 99 & 98 & 97\end{array}$

First published in the United States of America 1995 by

Scholarly and Reference Division,

ST. MARTIN'S PRESS, INC.,

175 Fifth Avenue,

New York, N.Y. 10010

ISBN 978-0-312-12404-5

Library of Congress Caltaloging-in-Publication Data

The move to the market? : trade and industry policy reform in

Iransitional ecomomics / edited by Paul Cook and Frederick Nixson.

p. cm. - (International political economy series)

Includes bibliegraphical references and index.

ISBN 978-0-312-12404-5

1. Frec enterprise-Devcloping countries-Congresses. 2. Free enterprise-Europe, Eastern-Congresses. 3. Post-communism-Economic aspects-Congresses. 4. Developing countries-Conmercial pulicy-Congresses. 5. Europe, Eastem-Commercial policy-

-Congresses. 6. Industrial policy-Developing countries-

-Congresses. 7. Industrial policy-Europe, Enstern-Congresses.

I. Cook, Paul, 1944- . II. Nixson, F. I. III. Series.

HC59.7.M68 1995

$338.9^{\prime} 009172^{\prime} 4-\mathrm{dc} 20$ 


\section{Contents}

List of Figures vii

List of Tables viii

List of Abbreviations $\quad \mathrm{x}$

Preface and Acknowledgements xii

Notes on the Contributors xiv

\section{Part I Introduction}

1 The Move to the Market 3

Paul Cook and Frederick Nixson

Part II The Transition to the Market: Some Theoretical Issues

2 Alternative Possibilities for Post-Communist Economies 29 Pat Devine

3 Transition to the Market: Some Implications for Human Resource Development

Diane Elson

4 Institutional Obstacles to Marketization in Post-Socialist Economies

Mo Yamin and Stephen Batstone

\section{Part III Eastern and Central Europe}

5 Economic Transformation in East and Central Europe:

An Overview

Peter Lawrence

6 The Impact of Economic Reform in East and Central Europe on Developing Countries

Mehdi Shafaeddin 


\section{Part IV Central, East and South-East Asia}

7 The Democratic People's Republic of Korea: The Reluctant Reformer

Frederick Nixson and Paul Collins

8 Lessons of Trade Policy and Economic Reform in China 123 Alasdair MacBean

9 The Evolution of Chinese Foreign Investment Policy Le-Yin Zhang and John Thoburn

10 Mongolia: The Painful Transition to a Market Economy Frederick Nixson

11 Privatization and Private-Sector Development in a Transitional Economy: The Case of Myanmar Paul Cook

12 Perestroika in South-East Asia: Industry and Trade in the Lao People's Democratic Republic Ian Livingstone

\section{Part V Sub-Saharan Africa}

13 Mozambique: The Market and Transition John Weiss

14 Trade and Industry in Zimbabwe:

Tidings Ndhlovu

\section{Part VI Conclusion}

15 Is the Market the Answer? Philip F. Leeson 


\section{List of Figures}

$\begin{array}{lll}5.1 & \text { Net material product } & 76\end{array}$

$\begin{array}{lll}5.2 & \text { Industrial production, 1970-91 } & 77\end{array}$

$\begin{array}{lll}5.3 & \text { Agricultural production, 1970-91 } & 77\end{array}$

5.4 Gross investment, 1970-91 78

$\begin{array}{ll}5.5 & \text { Export volumes, 1970-91 }\end{array}$

5.6 Import volumes, 1970-91 79

5.7 Unemployment rates, December 1990 and January $1992 \quad 80$

5.8 Inflation, $1990-91 \quad 81$

$\begin{array}{lll}5.9 & \text { Real wages, } 1988-91 & 82\end{array}$

5.10 Czechoslovakia, trade and payments, 1980-91 83

5.11 Hungary, trade and payments, 1970-91 84

5.12 Romania, trade and payments, 1972-91 85

5.13 Poland, trade and payments, 1976-91 86

5.14 External debt, convertible currencies, 1989-91 87 


\section{List of Tables}

1.1 Economic and political change in transitional economies 4

$\begin{array}{lll}1.2 & \text { Inflation in transitional economies } & 14\end{array}$

1.3 Growth of real GDP in transitional economies 15

1.4 Stabilization and reform in Eastern Europe 16

3.1 GNP and human development, 1985-7 44

3.2 Health profile, selected centrally-planned economies 45

3.3 Education profile, selected centrally-planned economies $\quad 46$

3.4 Social development in Kerala, 1989

5.1 Eastern Europe, male and female unemployment rates, September 1991

6.1 Trade of developing countries (DCs) with socialist countries in transition (SETs) and socialist countries of Asia,1980-9 100

6.2 Trade of selected countries with socialist countries in transition (SETs) 1987

6.3 Eastern Europe and the USSR: foreign trade by direction, 1988-90

6.4 Distribution of trade of USSR with major groups of partner countries, 1987-90

102

6.5 Various economic indicators for USSR and other Eastern European countries

103

10.1 Mongolia, major economic and structural reforms, 1990 and 1991

11.1 Relative shares of industrial subsectors in total gross value of industrial production, 1971/2 and 1983/4-1986/7 174

11.2 Structure of manufacturing value added, 1974/5-1984/5 176

11.3 Operating ratios of state economic enterprise, 1982-9 178

11.4 Output and capacity utilization of state enterprises, 1985/6-1989/90

11.5 Foreign investments in the Union Myanmar by sectors, 1989/90-1990/1

11.6 Private commercial loans and advances outstanding, 1989/90-1990/1

12.1 Lao PDR, balance of payments, 1984-7

12.2 Sectoral growth rates, planned and actual, in Lao PDR's Second Five-Year Plan, 1986-90

12.3 Public-sector industrial enterprises, 1987 
12.4 Distribution of domestic credit, 1982-7 202

12.5 Composition of credit extended by State Bank of Laos, 1983-7

12.6 Main product composition of output values of industrial enterprises supervised in 1982 by the Ministry of Industry (only), 1982-7

12.7 Laos: principal manufactured products, 1980 and $1990 \quad 205$

12.8 Distribution of total net energy supplied, by end-use, 1980-1

12.9 Estimated employment in state and private establishments, Vientiane Municipality, 1990

12.10 Numbers employed in industrial establishments under the Ministries of Industry, Culture and Public Health, 1989

12.11 Household ownership, tools and equipment in three villages, Vientiane Province, rural survey 1987

12.12 Size distribution of industrial establishments under the authority of the Ministries of Industry, Education and Culture, 1989

12.13 Official and market exchange rates, 1984-90 215

13.1 Some socialist African economies, comparative performance, percentage annual growth, 1980-8

13.2 Performance, macroeconomic indicators

14.1 Sectoral contribution to GDP selected activities, 1980-8 236

14.2 Whale among minnows 


\section{List of Abbreviations}

\begin{tabular}{ll} 
ADB & Asian Development Bank \\
ASEAN & Association of South East Asian Nations \\
cif & Carriage Insurance and Freight \\
CIS & Confederation of Independent States \\
CMEA & Council for Mutual Economic Assistance (Comecon) \\
CPE & Centrally-planned Economy \\
DFI & Direct Foreign Investment \\
DPRK & Democratic Peoples Republic of Korea \\
EC & European Community \\
EEC & European Economic Community \\
EFTA & European Free Trade Association \\
EPZ & Export Processing Zone \\
ERP & Effective Rate of Protection \\
fob & Free on Board \\
GATT & General Agreement on Tariffs and Trade \\
GDP & Gross Domestic Product \\
GDR & German Democratic Republic \\
GMP & Gross Material Product \\
GNP & Gross National Product \\
HDI & Human Development Index \\
IBRD & International Bank for Reconstruction and Development \\
ICOR & Incremental Capital Output Ratio \\
IMF & International Monetary Fund \\
ITC & International Trade Centre \\
JV & Joint Venture \\
LDC & Less Developed Country \\
MVA & Manufacturing Value Added \\
NGO & Non-Governmental Organization \\
NIC & Newly Industrialising Country \\
OECD & Organization for Economic Cooperation and Development \\
PTA & Preferential Trading Agreement \\
R\&D & Research and Development \\
RENAMO & Movement for National Resistance in Mozambique \\
SADCC & Southern African Development Coordination Conference \\
SET & Socialist Countries in Transition \\
SITC & Standard Industrial Trade Classification \\
& \\
\hline
\end{tabular}


SLORC State Law and Order Restoration Council

SoE State-owned Enterprises

SSE Small-Scale Enterprises

UNCTAD United Nations Conference on Trade and Development

UNCTC United Nations Centre for Transnational Corporations

UNDP United Nations Development Programme

UNIDO United Nations Industrial Development Organisation

USSR Union of Soviet Socialist Republics 


\section{Preface and Acknowledgements}

This volume is concerned with the economic issues raised by the move of the socialist and ex-socialist centrally planned economies towards more market-orientated economic systems. In particular, the contributors to the book examine the key role that trade and industrial sector policy reforms are likely to play in the process of transition.

The transitional process itself continues to be a topic of debate, both in terms of the concept itself and in terms of the means by which it is to be achieved. Prior to the 1980s, there was little previous experience either with countries relinquishing 'socialism' or totally abandoning central planning. The People's Republic of China led the way in 1978, followed by other Asian and African economies in the mid-1980s, and Eastern European economies and the former Soviet Union (USSR) towards the latter part of the 1980s. To varying degrees, these economies have undergone major economic reforms, which have lessened the direct control that governments exercised over economic affairs and have led to greater reliance being placed on the market mechanism.

There are differences of opinion concerning the speed with which reforms should be implemented and the relative emphasis to be given to specific reforms, as well as to their sequencing. There is also controversy concerning the extent to which economic reforms should be preceded or accompanied by political changes. Again, the degree to which countries have undertaken political reforms varies widely. Most of all, however, there is disagreement over the relative importance of stabilization and structural adjustment programmes. Proponents of the former tend to minimize the difficulties that may be encountered in establishing the institutions and economic environment necessary for a market-orientated economy. Those that emphasize the need for structural adjustment focus on supply-side issues but are often excessively 'price-ist' and underestimate the problems that constrain the emergence of a dynamic private sector. The relationship between the state and the market rarely features in these controversies.

The contributions to this volume throw some light on these issues through a number of carefully documented case studies which examine the way various countries have approached reform, with particular reference 
to the industrial and trade sectors. Most of the papers on which the chapters are based were delivered at a Workshop on trade and industry policy reform in transitional economies organised by the Development Studies Association Industry and Trade Study Group held at the University of Manchester.

The manuscript was mainly prepared by Lesley Bernardis of the Institute for Development Policy and Management (IDPM). The efficiency of her work and her patience with the Editors are more than gratefully acknowledged. Thanks go also to Jayne Hindle of IDPM and Sue Hilton, Sue Massey and Ann de Maestri of the School of Economic Studies.

Paul COOK FREDERICK NIXSON 


\section{Notes on the Contributors}

Stephen Batstone is Lecturer in SME Management at the University of Warwick, where he teaches in the area of entrepreneurship and small business. Prior to this he was a lecturer at Leicester Polytechnic and research assistant at Trent Polytechnic. He has published papers on several aspects of entrepreneurship.

Paul Collins is Principal Consultant, RIPA International and Head of Task Force at RIPA's Transitional Economies Centre. He is Editor of Public Administration and Development and a member of the IIAS Scientific Committee. He was previously Principal Adviser, UNDP Management Development Programme, New York and has published widely on development management.

Paul Cook is Senior Lecturer in the School of Economic Studies at the University of Manchester. He teaches macroeconomics and development economics. He is currently researching into privatization in developing and transitional economies. He has published Privatisation in Less Developed Countries and Macroeconomics for Developing Countries (with Colin Kirkpatrick).

Pat Devine is Senior Lecturer in the School of Economic Studies at the University of Manchester where he teaches industrial economics and comparative economic systems. He is joint author of An Introduction to Industrial Economics and author of Democracy and Economic Planning. $\mathrm{He}$ is currently working on models of participatory decision-making and European industrial strategy.

Diane Elson is Reader in Development Economics in the School of Economic Studies at the University of Manchester. Her research and teaching interests include trade, industrialization, structural adjustment and gender analysis. Her recent publications include Male Bias in the Development Process (editor) (1991), and 'Uneven development and the textiles and clothing industry', in L. Sklair (ed.) Capitalism and Development (1994).

Peter Lawrence is Lecturer in Economics at Keele University. He teaches development, micro and macro economics, and the economics of privati- 
zation. He is co-editor of Rural Cooperation in Tanzania and editor of The World Recession and the Food Crisis in Africa. He is also author of articles on African development, UK unemployment and privatization in Hungary.

Philip F. Leeson, now retired, was Director of Development Studies and Senior Lecturer in Economics at the University of Manchester. His main teaching activity was in courses in development economics for postgraduate students. His most recent publication was as editor (with M.M. Minogue) and contributor to Perspectives on Development (1990).

Ian Livingstone is Professor of Development Economics in the School of Development Studies at the University of East Anglia, Norwich. His main publications include Rural Development, Employment and Incomes in Kenya (1986); Irrigation Economics in Poor Countries (1982); Development Economics and Policy: Readings (1981); Lao PDR: Industrial Transition (1994); and Agro-Industry for Rural Employment Generation in Vietnam (1994).

Alasdair MacBean is Emeritus Professor of Economics at Lancaster University. He is also Visiting Professor, Fudan and Peoples' Universities, China. He teaches international trade and development. He is currently engaged in research on export promotion in East Asia-lessons for East European economies. He is author of Export Instability and Economic Development (1966); and Commodity Policies: Problems and Prospects (1987, with Tim Nguyen).

Tidings Ndhlovu is Lecturer in Economics at the Manchester Metropolitan University (formerly Lecturer in Economics at the University of Manchester, UMIST and the University of East Anglia and part-time lecturer in Economics at the Universities of Essex, Liverpool and Bradford). His main teaching areas include: development economics, micro/macro economics, principles of economics, policies of the EU (formerly EEC), international trade and development, and economics for health studies. His most recent book is Development Strategies in Zimbabwe: Rhetoric and Reality.

Frederick Nixson is Reader in the School of Economic Studies at the University of Manchester. He teaches development economics and has a research interest in transnational corporations and economic reform in transitional economies. He has published Economics of Change in Less 
Developed Countries (with David Colman), and Industrial Structure and Policy in Less Developed Countries (with Norman Lee and Colin Kirkpatrick).

Mehdi Shafaeddin is Officer-in-Charge, Trade Policy Analysis Section, International Trade Division, UNCTAD. He has published widely in the field of international trade and development. He is author of Fallacies in Trade Policies: Recent Experience of Developing Countries.

John Thoburn is Reader in Economics at the University of East Anglia, and author or co-author of Primary Commodity Exports and Economics Development (1977), Multinationals, Mining and Development (1981), Foreign Investment in China Under the Open Policy (1990), Industrial Subcontracting in the UK and Japan (1992), and Tin in the World Economy (1994).

John Weiss is Senior Lecturer in the Development and Project Planning Centre at the University of Bradford. He is an author of Industry in Developing Countries (1990) and joint author of Project Analysis in Developing Countries (1992).

Mo Yamin is Lecturer in International Business at the Manchester School of Management, UMIST. He has written extensively on the activities of transnational companies and his recent research has focused on institutional aspects of TNC behaviour and the impact of TNCs on the transition process in Eastern Europe.

Le-Yin Zhang was born and educated in China. She received her Ph.D. from University College London, in 1991 and after that studied in Germany. She is currently working as a researcher in the China Regional Development Project in the University of Greenwich, London. 